\title{
Transaksi Lindung Nilai Syariah di Pasar Berjangka Komoditi Perspektif Dewan Syariah Nasional
}

\author{
Bobby Iskandar ${ }^{1 *}$ \\ ${ }^{1}$ UIN Raden Fatah Palembang, Indonesia
}

\begin{abstract}
Abstrak: Tujuan penelitian ini adalah untuk menganalisis ekonomi dan fikih atas Fatwa Dewan Syariah Nasional No. 96/DSN-MUI/IV/2015 Tentang Transaksi Lindung Nilai Syariah di Pasar Berjangka Komoditi. Jenis penelitian ini adalah deskriptif kualitatif, dengan data berupa transkrip Fatwa Dewan Syariah Nasional No. 96/DSN-MUI/IV/2015 tentang Transaksi Lindung Nilai Syariah di Pasar Berjangka Komoditi. Data yang diperoleh dianalisis secara interaktif dan terusmenerus sampai tuntas menggunakan model Miles dan Huberman, yaitu reduksi data, penyajian data, dan diverifikasi atau disimpulkan. Hasil penelitian menyimpulkan: (1) Analisis fikih atas fatwa Dewan Syariah Nasional No. 96/DSN-MUI/IV/2015 tentang Transaksi Lindung Nilai Syariah di Pasar Berjangka Komoditi, ditemukan adanya pandangan yang berbeda terhadap dalil-dalil yang ditemukan. Ulama yang melarang perdagangan berjangka komoditi, mengkaji dari syarat-syarat akad, di mana barang obyek akad harus ada pada penjual atau jelas keberadaan barangnya, adanya unsur spekulasi (gharar), serta penetapan margin yang persentasenya berkisar antara 5-10\% dalam Islam dapat masuk ke dalam kategori riba. Sedangkan yang memperbolehkan berpendapat dengan alasan meskipun barang belum ada tapi dapat diadakan dan diserahkan kemudian, diperbolehkan memperjualbelikannya, dan memandang perdagangan berjangka tidak dapat dikategorikan dengan spekulasi; dan (2) Analisis ekonomi Islam atas fatwa Dewan Syariah Nasional No. 96/DSNMUI/IV/2015, di antaranya produsen komoditi dapat menjual komoditi yang baru akan mereka panen beberapa bulan kemudian pada harga yang telah dipastikan atau disepakati sebelum panen dilakukan. Dengan demikian, mereka dapat memperoleh jaminan harga sehingga tidak terpengaruh oleh kenaikan/penurunan harga jual di pasar tunai. Sedangkan eksportir dapat melakukan pembelian komoditi di masa yang akan datang, pada saat harus memenuhi kontraknya dengan pembeli di luar negeri, atau pengolah yang harus melakukan pembelian komoditi secara berkesinambungan. Selain itu juga, Pasar Berjangka Komoditi dapat dijadikan sebagai sarana pembentukan harga yang transparan dan wajar, yang mencerminkan kondisi pasokan dan permintaan yang sebenarnya dari komoditi yang diperdagangkan. Harga yang terjadi di bursa umumnya dijadikan sebagai harga acuan (reference price) oleh dunia usaha, termasuk petani dan produsen/pengusaha kecil, untuk melakukan transaksi di pasar fisik.
\end{abstract}

Kata Kunci: fikih, ekonomi, fatwa MUI, transaksi lindung nilai

\begin{abstract}
The purpose of this study is to analyze the economics and fiqh of the National Sharia Council Fatwa No. 96/DSN-MUI/IV/2015 concerning Shariah Hedging Transactions in the Commodity Futures Market. This type of research is descriptive qualitative, with data in the form of a transcript of the National Sharia Council Fatwa No. 96/DSN-MUI/IV/2015 concerning Sharia Hedging Transactions in the Commodity Futures Market. The data obtained were analyzed interactively and continuously to completion using the Miles and Huberman model, namely data reduction, data presentation, and verified or concluded. The results of the study conclude: (1) Fiqh
\end{abstract}

\footnotetext{
* Corresponding Author: Bobby Iskandar (bobbyiskan@gmail.com). UIN Raden Fatah Palembang, Indonesia
} 
analysis of the fatwa of the National Sharia Council No. 96/DSN-MUI/IV/2015 concerning Sharia Hedging Transactions in the Commodity Futures Market, it is found that there are different views on the arguments found. Scholars who prohibit commodity futures trading, examine the terms of the contract, where the object of the contract must be with the seller or the existence of the goods is clear, there is an element of speculation (gharar), as well as the determination of margins whose percentage ranges from $5-10 \%$ in Islam can be accepted. into the category of usury. Meanwhile, those who allow opinions on the grounds that although the goods do not yet exist but can be held and delivered later, are allowed to trade them, and view that futures trading cannot be categorized as speculation; and (2) Islamic economic analysis of the fatwa of the National Sharia Council No. 96/DSNMUI/IV/2015, among which commodity producers can sell the new commodity they will harvest a few months later at a price that has been confirmed or agreed upon before harvesting is carried out. Thus, they can obtain price guarantees so that they are not affected by increases/decreases in selling prices in the cash market. Meanwhile, exporters can purchase commodities in the future, when they must fulfill their contracts with overseas buyers, or processors who must purchase commodities on an ongoing basis. In addition, the Commodity Futures Market can be used as a means of establishing transparent and fair prices, which reflect the actual supply and demand conditions of the traded commodities. Prices that occur on the stock exchange are generally used as reference prices by the business world, including farmers and producers/small entrepreneurs, to conduct transactions in the physical market.

Keywords: fiqh, economics, MUI fatwa, hedging transactions

\section{Pendahuluan}

Pertumbuhan ekonomi disertai dengan tingkat inflasi yang stabil selama beberapa tahun terakhir. Inflasi harga bergejolak semakin ditekan. Kemudian menghasilkan tingkat inflasi umum pada kisaran target pemerintah. Selain itu juga, prekembangan ekonomi dipengaruhi oleh perdagangan bebas antar negara. Perdagangan antar negara akan lebih rumit karena adanya mata uang yang berbeda yang digunakan masing-masing negara. Penggunaan mata uang yang berbeda ini akan menjadi salah satu risiko dalam perdagangan antar negara karena perubahan nilai tukar mata uang.

Perdagangan pada sektor barang dan jasa, dengan disepakatinya perjanjian perdagangan internasional oleh World Trade Organisation (WTO) sangat sulit diharapkan lagi dapat diciptakan atau dipertahankan kebijakan pemerintah yang bersifat membatasi atau menghambat arus barang dan jasa yang mengalir sejalan arus globalisasi. Bahkan berbagai pengaturan perdagangan komoditas yang dilakukan atas kesepakatan internasional tampaknya tidak bisa bertahan dan mati secara alamiah seperti International Natural Rubber Organisation (INRO), dan International Coffee Organisation (ICO) (Kuenaen \& Ridwan, 2001).

Kehadiran Bursa Berjangka yang memperdagangkan kontrak berbagai macam komoditas, terbentuklah harga secara efisien dan transparan. Harga yang terbentuk dapat diakses secara luas melalui berbagai sarana komunikasi seperti radio, televisi, koran dan alat komunikasi lainnya, sehingga informasi harga yang terjadi di bursa dapat diketahui oleh para petani. Atas dasar informasi tersebut, petani dapat mengendalikan usahanya dengan memutuskan akan menanam atau tidak. Apabila diputuskan untuk menanam atau memproduksi, dapat memperkirakan kapasitasnya tergantung pada trend harga yang terjadi di bursa.

Petani dalam arti luas yaitu yang bergerak di bidang tanaman pangan, perkebunan, perikanan, dan peternakan ini secara bertahap harus 
diberdayakan dan diperkenalkan dengan berbagai instrumen modern seperti perbankan, asuransi, dan berbagai instrumen manajemen risiko (risk management) antara lain adalah Perdagangan Berjangka Komoditi (Futures Trading). Di negara lain, misalnya Malaysia. Konsep lindung nilai syariah yang diterapkan di Malaysia sedikit berbeda dengan Indonesia. Jika Indonesia dalam menggunakan lindung nilai syariah didasarkan pada 3 akad di atas, maka di Malaysia konsep lindung nilai syariah menggunakan setidaknya 4 akad, yaitu akad tawarruq, bai' al-'inah, wa'ad, dan bai' al-sarf. Konsep lindung nilai syariah yang ada di Malaysia dapat dilihat dalam Islamic FX Swap, yaitu dengan biasanya melibatkan dua pertukaran mata uang asing, yaitu diawal dan pada saat jatuh tempo. Double exchange ini membuat $F X$ Swap berbeda dengan kontrak forward. Dalam kontrak forward, pertukaran hanya terjadi sekali. Misalnya, satu pihak ingin mengubah mata uang dolar AS (USD) menjadi ringgit mata uang Malaysia (MYR). Setelah bertukar antara USD dengan MYR, kontrak forward akan berakhir. MYR tidak akan diubah kembali ke USD dalam kontrak forward (Yakubu \& Dasuki, 2019).

Perdagangan berjangka secara tidak langsung dapat memotivasi atau mengarahkan para petani untuk menghasilkan komoditas yang bermutu sesuai dengan standar komoditas yang diperdagangkan di Bursa Berjangka. Mutu komoditas yang semakin baik memungkinkan pihak pengelola gudang menyimpan dan memberikan jaminan keamanan dan terpeliharanya mutu komoditas tersebut dengan baik dalam jangka waktu yang relatif panjang. Tanda bukti penyimpanan tersebut dapat digunakan oleh petani untuk mendapat pinjaman dari bank maupun menjualnya secara langsung. Dengan demikian, petani mempunyai dua pilihan yaitu menjual atau tidak menjual secara langsung pada saat panen dengan terlebih dahulu menyimpan di gudang, karena pada umumnya pada saat panen harga komoditas turun (Kuenaen \& Ridwan, 2001).

Perdagangan berjangka di kalangan dunia usaha dijadikan sebagai sarana lindung nilai (hedging) yang sangat efektif untuk menunjang kemanfaatan strategi manajemen perusahaan dari pengaruh timbulnya risiko atau kerugian yang disebabkan karena fluktuasi harga. Selain itu, perdagangan berjangka dapat digunakan sebagai sarana alternatif investasi bagi para pihak yang bermaksud untuk menanamkan (menginvestasikan) modalnya di Bursa Berjangka.

Sistem perdagangan berjangka mempunyai kesamaan dengan transaksi salam atau jual beli pesanan yang sudah dikenal pada masa Nabi Muhammad Saw. Mencermati pertumbuhan dan perkembangan ekonomi modern saat ini, Yusuf Qordhawi mengemukakan bahwa zaman ini penuh dengan berbagai persoalan dunia usaha (bisnis) dan persoalan-persoalan baru di bidang ekonomi dan keuangan. Bursa Berjangka sebagai persoalan perekonomian kontemporer harus dikaji dan dibahas secara komprehensif dari sudut pandang hukum Islam, agar memberikan jawaban terhadap persoalan kontemporer tersebut.

Persoalan perekonomian kontemporer tidak banyak dibahas secara rinci dalam Al-Qur'an dan Sunah karena dalam Al-Qur'an maupun Sunah lebih banyak menyajikan ketentuan yang umum. Akan tetapi dibahas dalam sumber hukum Islam yang lain yaitu melalui ijma' (kesepakatan para ulama) yaitu menggunakan ijtihad. Sebagian umat Islam meragukan kehalalan praktik Perdagangan Berjangka Komoditi karena khawatir mengandung gharar. Dengan pertimbangan untuk memperoleh manfaat dan menghindari mudhorat, persoalan ini perlu dikaji secara serius dan mendalam, agar dapat dipraktikkan dengan berpegang pada aturan hukum 
yang ada, baik hukum nasional maupun hukum Islam, sehingga tidak ada lagi keraguan untuk melakukan bisnis ini dalam usaha menghadapi era modernisasi melalui mekanisme lindung nilai.

Mekanisme lindung nilai terdiri atas transaksi yang berlawanan antara posisi di pasar fisik dengan posisi di pasar berjangka yang bertujuan untuk melindungi perusahaan dari pengaruh pergerakan harga di pasar berjangka yang bertujuan untuk melindungi perusahaan dari pengaruh pergerakan harga pasar fisik yang tidak sesuai dengan diperkirakan sebelumnya. Menyikapi hal tersebut, Dewan Syariah Nasional mengeluarkan fatwa tentang transaksi lindung nilai syariah atas nilai tukar (Islamic Hedging).

Fatwa No. 96/DSNMUI/ IV/2015 tentang Transaksi Lindung Nilai Syariah (al-Tahawwuth al-Islami/Islamic Hedging) atas Nilai Tukar. Permasalahan transaksi lindung nilai syariah atas nilai tukar ini sudah dibahas dalam waktu yang lama oleh DSN-MUI dan sudah muncul sejak ada pergeseran tugas pengawasan perbankan dari Bank Indonesia kepada Otoritas Jasa Keuangan (OJK). Paparan risiko dalam mata uang asing memerlukan lindung nilai dalam rangka memitigasi risiko ketidakpastian pergerseran nilai tukar telah menjadi pertimbangan dalam penerbitan fatwa ini.

Dewan Syariah Nasional melalui fatwanya tersebut menyatakan, bahwa terdapat tiga jenis akad yang menjadi ketentuan dalam melaksanakan transaksi lindung nilai syariah atas nilai tukar (Islamic hedging) yaitu sebagai berikut.

a. Aqd al-Tahawwuth al-Basith (transaksi lindung nilai sederhana) adalah transaksi lindung nilai dengan skema forward agreement yang diikuti dengan transaksi spot pada saat jatuh tempo serta penyelesaiannya berupa serah terima mata uang. b. Aqd al-Tahawwuth al-Murakkab (transaksi lindung nilai kompleks) adalah transaksi lindung nilai dengan skema berupa rangkaian transaksi spot dan forward agreement yang diikuti dengan transaksi spot pada saat jatuh tempo serta penyelesaiannya berupa serah terima mata uang.

c. Aqd al-Tahawwuth fi Suq al-Sil'ah (transaksi lindung nilai melalui bursa komoditi syariah) adalah transaksi lindung nilai dengan skema berupa rangkaian transaksi jual beli komoditi (sil'ah) dalam mata uang asing serta penyelesaiannya berupa serah terima mata uang pada saat jatuh tempo.

Fatwa DSN tentang bolehnya hedging syariah tersebut bertentangan dengan hasil ijtimak ulama seluruh dunia di bawah OKI No. 65 tentang pasar modal, menyatakan bahwa: (1) pertukaran tersebut harus dilaksanakan secara tunai (spot) artinya masing-masing pihak harus menerima atau menyerahkan masing-masing mata uang pada saat yang bersamaan; (2) motif pertukaran adalah dalam rangka mendukung transaksi komersial, yaitu transaksi perdagangan barang dan jasa antar bangsa; (3) harus dihindari jual beli bersyarat, misalnya A setuju membeli barang dari B haru ini dengan syarat B harus membelinya kembali pada tanggal tertentu dimasa yang akan datang; (4) transaksi berjangka harus dilakukan dengan pihakpihak yang diyakini mampu menyediakan valuta asing yang dipertukarkan; dan (5) tidak dibenarkan menjual barang yang belum dikuasai atau jual beli tanpa hak kepemilikan. Dengan demikian, dapat dinyatakan bahwa syariat tidak membolehkan jual beli mata uang secara tidak tunai, dan tidak membolehkan janji (wa'ad) dalam transaksi penukaran mata uang. Keputusan ini berdasarkan al-Qur'an, as-Sunah dan Ijma para ulama. 
Mengkaji aqad dalam hedging syariah (alTahawwuth al-Islami) tersebut masih belum bisa dengan jelas menentukan sifat dari suatu transaksi tersebut, dimana secara teori hedging timbul didasari oleh ketidakpastian akan masa yang akan dating (Sutedi, 2012). Selanjutnya bagaimana cara melihat ataupun mengukur suatu transaksi tersebut bahwa transaksi yang dikerjakannya tersebut tidak didasari oleh ketidakpastian atau spekulasi.

Aqad hedging syariah dalam skemanya terjadi penangguhan dimana kedua pihak melakukan perjanjian terlebih dahulu kemudian serah terima mata uang pada saat tempo waktu yang ditentukan. Salah satu syarat dalam transaksi mata uang adalah dilakukan secara spot atau kontan dan tidak adanya penangguhan waktu baik dari kedua pihak maupun salah satunya. Jika syarat tersebut tidak terpenuhi, maka akadnya menjadi fasid (batal) karena dalam serah terima dua barang yang saling dipertukarkan mesti terlaksana sebelum berpisah (Az-Zuhaili, 2011). Adapun salah satu dalil riwayat Muslim dari Abu Sa'id al-Khudri, Nabi Saw bersabda: "Dari Abu Sa'id al-Khudri, sesungguhnya Nabi saw. bersabda: Janganlah kamu menjual emas dengan emas kecuali sama (nilainya) dan janganlah menambahkan sebagian atas sebagian yang lain; janganlah menjual perak dengan perak kecuali sama (nilainya) dan janganlah menambahkan sebagian atas sebagian yang lain; dan janganlah menjual emas dan perak tersebut yang tidak tunai dengan yang tunai."

Hadis Nabi Saw. di atas menjelaskan bahwa dalam aqad sharf diharuskan adanya serah terima barang sebelum kedua pihak yang melakukan akad berpisah diri. Hal itu agar tidak terjatuh pada riba nasiah (riba penangguhan).

\section{Metode Penelitian}

Adapun jenis penelitian ini adalah penelitian kepustakaan (library research). Sumber data dalam penelitian ini berupa data primer dan sekunder. Data primer yaitu data yang diperoleh langsung dari sumber, yaitu Fatwa Dewan Syariah Nasional No.96/DSN-MUI/IV/2015 tentang Transaksi Lindung Nilai Syariah (al-Ahawwuth alIslami/Islamic Hedging) atas nilai tukar (pasar berjangka komoditi: aspek fikih dan ekonomi), sedangkan data sekunder diperoleh dari berbagai buku, jurnal, hasil penelitian terdahulu, dan artikelartikel yang berkaitan sebagai bahan referensi. Pengumpulan data penelitian ini menggunakan metode dokumentasi, yaitu berupa laporan pemerintah atau Fatwa MUI atau hasil penelitian. Analisis data adalah rangkaian kegiatan penelaahan, pengelompokan, sistematisasi, penafsiran dan verifikasi data, agar sebuah fenomena memiliki nilai sosial, akademis, dan ilmiah.

\section{Hasil Penelitian dan Pembahasan}

\section{Analisis Fikih atas Fatwa DSN No.96/DSN- MUI/IV/2015 tentang Transaksi Lindung Nilai Syariah di Pasar Berjangka Komoditi}

Kontrak Berjangka futures adalah kontrak antara dua pihak untuk membeli (long position) atau menjual (short position) suatu komoditi dengan harga komoditi tertentu untuk penyerahan di masa depan melalui mekanisme bursa yang terorganisasi. Kontrak Berjangka futures dilaksanakan melalui bursa di pasar berjangka komoditi. Berdagang komoditi di lantai bursa, pedagang harus menjadi anggota bursa atau bisa melalui pialang (broker) yang menjadi anggota bursa. Layak tidaknya seseorang atau suatu badan hukum menjadi anggota bursa akan ditentukan berdasarkan kredibilitas usaha, karakter dan 
integritas calon anggota. Selain itu juga, semua pengguna pasar berjangka dipersyaratkan menyerahkan sejumlah uang yang disebut dengan margin yang besarnya per kontrak umumnya berkisar antara 5-10\% dari nilai kontrak. Besarnya margin yang berbeda-beda tergantung pada komoditi, waktu, dan gejolak harga yang terjadi.

Pengertian margin dalam Undang-Undang Republik Indonesia No. 32 Tentang Perdagangan Berjangka Komoditi, adalah sejumlah uang atau surat berharga yang harus ditempatkan oleh Nasabah pada Pialang Berjangka, Pialang Berjangka pada Anggota Kliring Berjangka, atau Anggota Kliring Berjangka pada Lembaga Kliring Berjangka untuk menjamin pelaksanaan transaksi Kontrak Berjangka. Margin dimungkinkan memerlukan tambahan (margin call) karena berkurang dari margin awalnya karena pergerakan harga yang berlawanan dengan yang diperkirakannya semula. Bila saldo margin mencapai batas tertentu, kepada setiap, nasabah yang memiliki posisi terbuka, baik beli atau jual, harus menambah marginnya ke besaran semula (margin awal). Margin yang telah ditetapkan berlaku untuk periode waktu tertentu dan dapat diubah sesuai dengan situasi dan kondisi yang ada. Selain itu, ada biaya komisi yang dikenakan oleh pialang berjangka yang besaran minimumnya ditetapkan bursa atas persetujuan Badan Pengawasan Perdagangan Berjangka Komiditi.

\section{Syamsul Anwar (2007) dalam Seminar} Nasional Perdagangan Berjangka Komoditi Ditinjau dari Segi Hukum Islam, menyatakan bahwa ditinjau dari perspektif hukum Islam, perdagangan berjangka komoditi masih dipersoalkan. Persoalan muncul karena objek perjanjian dalam kontrak tersebut belum ada pada saat kontrak ditutup. Di samping itu, hedging dengan mengalihkan risiko-spkulatif yang tampaknya bernuansa spekulasi (gharar) juga dipersoalkan, atau penetapan margin yang persentasenya berkisar antara 5-10\% dalam Islam dapat masuk ke dalam kategori riba, karena telah ditentukan berapa pembagian yang semestinya harus diterima oleh salah satu pihak tertentu dari pihak-pihak yang bertransaksi itu. Berdasarkan kajian terhadap fikih klasik berkesimpulan bahwa, kontrak berjangka bila dilihat dari perspektif pandangan mayoritas ulama klasik mau tidak mau harus dipandang tidak sah, karena kontrak itu dibuat terhadap objek yang belum ada. Namun, di samping pandangan mayoritas tersebut, juga terdapat pendapat minoritas ulama yang bisa dijadikan rujukan untuk membolehkannya.

Perbedaan pendapat ulama klasik tersebut tampaknya sangat berpengaruh hingga kini. Dalam hukum Islam, terhadap fenomena perdagangan berjangka terdapat pendapat yang melarang dan membolehkannya. Ketika membahas persoalan kontrak berarti sama dengan membicarakan akad dalam sistem muamalah, sementara akad sendiri mempunyai syarat-syarat umum, yang dapat disebutkan di sini yaitu yang berkaitan langsung dengan permasalahan, di antaranya:

a. Objek akad itu diakui oleh syara', atau objek akad itu bukan barang yang haram dan objek akad harus ada dan dapat diserahkan ketika berlangsungnya akad, karena memperjualbelikan sesuatu yang belum ada dan tidak mampu diserahkan hukumnya tidak sah. Hal ini berdasarkan hadis, yaitu tidak sah menjual sesuatu barang yang tidak berada padanya. Artinya, tidak dibolehkan memperjualbelikan barang yang tidak nyata wujudnya di hadapannya atau tidak dalam kepemilikannya secara sah. Meskipun demikian, bagi sebagian ulama fikih mengecualikan beberapa bentuk akad yang barangnya belum ada, seperti 
jual beli pesanan (bai' salām, yaitu disebut juga penjualan dengan kriteria tertentu dengan penangguhan penyerahan tetapi menyegerakan pembayaran/advanced payment pada saat kontrak dibuat, di mana pada saat itu kedua pihak melakukan perkiraan harga berdasarkan penilaian rasional), istisna $\bar{a}$, ijārah, dan musāqah (transaksi antara pemilik kebun dan pengelolanya). Alasan pengecualian ini adalah karena akad-akad seperti ini amat dibutuhkan masyarakat dan telah menjadi kebiasaan mereka melakukan akad-akad seperti ini.

b. Akad yang dilakukan memenuhi syaratsyarat khusus dengan akad yang bersangkutan. Artinya, di samping memenuhi syarat-syarat umum, akadakad khususnya juga harus dipenuhi.

c. Akad itu bermanfaat, oleh sebab itu jika seseorang melakukan suatu akad dan imbalan yang diambil merupakan kewajiban baginya, maka akad itu batal. Misalnya seseorang yang melakukan akad dengan orang lain bahwa ia menghentikan kejahatannya, jika ia diberi sejumlah uang (ganti rugi).

d. Ijab tetap utuh dan sahih sampai terjadinya kabul. Apabila ijab tidak utuh dan tidak sahih lagi ketika kabul diucapkan, maka akad itu tidak sah. Hal ini kerap dijumpai dalam suatu akad melalui tulisan. Misalnya, dua orang pedagang dari daerah yang berbeda melakukan transaksi dagang melalui surat. Sebelum surat yang mengandung ijab itu sampai kepada pihak penjual, pembeli telah wafat atau gila. e. Ijab dan kabul dilakukan dalam suatu majelis, yaitu suatu keadaan yang menggambarkan proses suatu transaksi.

f. Tujuan akad itu jelas dan diakui syara'. Tujuan akad ini terkait dengan berbagai bentuk akad yang dilakukan.

Hal yang paling krusial dalam perdagangan berjangka komoditi ini adalah ketika para spekulator berani mengambil risiko yang akan terjadi di masa akan datang dan juga persoalan keberadaan objek yang dikontrakkan tidak berwujud pada saat akad dilangsungkan dan juga penetapan margin yang begitu besar mulai dari 5$10 \%$, dapat memberatkan salah satu pihak, apalagi telah ditetapkan di awal yang masuk ke dalam kategori riba. Selain mencermati masalah akadnya, jika dilihat dari penetapan margin, sesuai dengan Surat an-Nisā' ayat 197.

Quraish Shihab (2000) menafsirkan ayat di atas, melarang memakan harta di antara kamu secara batil, yakni yang tidak sesuai dengan tuntunan syariat, tetapi hendaklah dilakukan dengan jalan perniagaan berdasarkan kerelaan di antara kamu, yakni kerelaan yang tidak melanggar ketentuan agama. Selain itu juga, seperti yang telah disebutkan sebelumnya jika ternyata dalam marginnya telah ditentukan persentasinya, bahkan penetapan marginnya sangat besar, sehingga dapat dikategorikan riba, maka dalil yang mendukung adanya riba yang paling mendekati bagi persoalan tersebut adalah QS Ali Imron Ayat 130.

Rahman (1996), mengemukakan dampak dari memakan riba yaitu dapat menyebabkan tamak, kikir, dan egois bagi orang yang mengambilnya; dan kebencian, kemarahan, permusuhan dan kecemburuan bagi orang yang membayarnya. 
Berdasarkan beberapa dalil yang dikemukakan di atas, dinyatakan adanya ulama berbeda pendapat karena perbedaan persepsi dan batasan tentang dalil-dalil yang membicarakannya. Adapun ulama yang melarang perdagangan berjangka, berangkat dari tinjauan terhadap syaratsyarat akad yaitu akad baru dapat terpenuhi jika waktu akad dibuat, barang obyek akad harus ada pada penjual atau jelas keberadaan barangnya. Juga bahwa obyek jual beli harus merupakan barang yang dimiliki oleh penjual atau mendapatkan izin dari pemiliknya, jika barang itu bukan milik si penjual.

Pendapat sebagian kecil ulama yang memperolehkan perdagangan berjangka komoditi, juga bedasarkan dalil tersebut di atas yang digunakan oleh sebagian besar ulama tersebut. Ibnu Qayyim, memandang bahwa illat jual beli gharar dan sesuatu yang tidak ada pada penjual tersebut, adalah ketidakpastian tentang barang itu dapat diserahkan atau tidak, atau kriterianya bukan terletak pada ada atau tidak adanya, melainkan terletak pada dapat tidaknya barang tersebut diserahkan pada waktu ditentukan. Larangan tersebut menyangkut jual beli benda tertentu dan tidak meliputi barang dalam tanggungan. Demikian pula menurut Ibnu Taimiyah bahwa meskipun barang belum ada tapi dapat diadakan dan diserahkan kemudian, diperbolehkan memperjualbelikannya. Sebaliknya, seorang ulama besar India Arqam Khan mengatakan perdagangan seperti itu tidak dibolehkan atau tidak sah menurut hukum dengan alasan karena benda komoditinya tidak diserahkan di tempat membuat perdagangan, pendapat ini merujuk kepada tafsir jumhur (Fatum, 2013). Lain halnya dengan ulama kontemporer Hasim Kamali dan Yusuf Musa seorang yang liberal memboleh perdagangan jenis ini, karena memanfaatkan ada yang namanya kliring house disebabkan ada jaminan. Secara syari'ah tidak bertentangan dengan asas-asas hukum dan maqasis syari'yah.

Gharar di dalam bisnis menurut pandangan Rahman (1996), berarti melakukan sesuatu secara membabibuta tanpa pengetahuan yang mencukupi; atau mengambil risiko sendiri dari suatu perbuatan yang mengandung risiko tanpa mengetahui dengan persis apa akibatnya, atau memasuki kancah risiko tanpa memikirkan konsekuensinya. Dalam segala situasi tersebut, disitu selalu hadir risiko.

Demikian pula menurut Ibnu Taimiyah bahwa gharar itu dilibatkan apabila seseorang tidak tahu apa yang tersimpan bagi dirinya pada akhir suatu kegiatan bisnis juial beli. Setiap jenis kontrak yang bersifat open-ended mengandung unsur gharar. Sehingga dapat dibagi gharar menjadi dua kelompok:

a. Kelompok pertama adalah unsur risiko yang mengandung keraguan, probabilitas dan ketidakpastian secara dominan.

b. Kelompok kedua unsur meragukan yang dikaitkan dengan penipuan atau kejahatan oleh salah satu pihak terhadap pihak lainnya (Rahman, 1996).

Berdasarkan pandangan Afzalur Rahman dan Ibnu Taimiyah di atas, bahwa adanya dalil yang sama tetapi dengan pemaknaan illat yang berbeda, sehingga hukum yang dihasilkan juga jelas akan berbeda. Dalam hal adanya pelarangan judi yang berkenaan dengan permainan transfer risiko spkulaitf (hedging) dalam perdagangan berjangka komoditi, juga masih dalam perdebatan. Artinya, ada yang menyamakan perdagangan berjangka ini dengan judi dan ada pula yang memandang bahwa hal tersebut tidak dapat dikategorikan dengan judi.

Perbedaan di atas juga dinyatakan Anwar (2007) sebagai berikut: 
a. Judi menciptakan risiko bagi para pihak yang terlibat di dalam, karena dengan membeli nomor mislnya berarti orang itu menghadapkan diri kepada risiko hilangnya obyek yang dipertaruhkan. Kalau nomornya keluar, mendapat untuk, tetapi kalau tidak keluar ia mengalami kerugian karena risiko yang ia ciptakan sendiri. Sedangkan hedging justru merupakan sarana menanggulangi risiko yang sudah ada dalam bisnis. Petani yang menjual kontrak berjangka melindungi diri dari risiko jatuhnya harga di masa depan atau pedagang yang membeli kontrak berjangka melindungi diri dari risiko kenaikan harga yang bisa menggoyahkan keuangan usahanya.

b. Judi tidak mempunyai fungsi ekonomi yang berarti bagi masyarakat secara keseluruhan. Sedangkan hedging mempunyai fungsi ekonomi yang penting seperti pencipta harga yang stabil.

c. Judi membangkitkan angan-angan kosong pada seseorang untuk mendapatkan keuntungan dengan jalan pintas, dan investasi dalam bentuk pembelian tiket pertaruhan tidak memberikan jaminan kembalian keuntungan bagi investor tersebut. Sedangkan hedging di dalamnya para spekulator tidak menciptakan risiko tetapi memikulnya dan dengan cara itu, mereka mempermudah dan pemasaran dan memperlancar perdagangan komoditas dan menjembatani antara pembeli dan penjual sehingga biaya pasar akan lebih murah.

Pemikiran lainnya dikemukakan Nordin (2014), bahwa konsep lindung nilai berkaitan dengan prinsip Islam sebagaimana terdapat kaidah fikih al-ddharu yuzalu (kemudaratan dihilangkan). Bahkan terdapat lagi kaidah fikih yang secara subtansi mengharuskan untuk memnimalisir risko dan melindung nilai. Selain itu, dalam Islam terdapat kontrak-kontrak yang berbentuk jaminan seperti al-rahnu (gadaian).

Kaidah-kaidah yang berkenaan dengan kemudaratan di antaranya terdapat pada Q.S. AlAn'am ayat 119. Ayat ini menjelaskan bahwa tidak semua keterpaksaan itu membolehkan yang haram, namun keterpaksaan itu dibatasi dengan keterpaksaan yang benar-benar tiada jalan lain kecuali hanya melakukan itu, dalam kondisi ini maka semua yang haram dapat diperbolehkan memakainya. Misalkan seorang di hutan tiada makanan sama sekali kecuali ada babi hutan dan bila ia tidak makan menjadi mati, maka babi hutan itu boleh dimakan sebatas keperluannya. Batasan Kemudharatan adalah suatu hal yang mengancam eksistensi manusia, yang terkait dengan panca tujuan, yaitu memelihara agama, memelihara jiwa, memelihara akal, memelihara keturunan dan memelihara kehormatan atau harta benda. Dengan demikian darurat itu terkait dengan Dharuriah, bukan hajiah dan tahsaniah.

Az-Zuhaili (2011) membagi kepentingan manusia akan sesuatu dengan 4 klasifikasi, yaitu:

a. Darurat, yaitu kepentingan manusia yang diperbolehkan menggunakan sesuatu yang dilarang, karena kepentingan itu menempati puncak kepentingan kehidupan manusia, bila tidak dilaksanakan maka mendatangkan kerusakan. Kondisi semacam ini memperbolehkan segala yang diharamkan atau dilarang, seprti memakai sutra bagi laki-laki yang telanjang, dan sebagainya. 
b. Hajah, yaitu kepentingan manusia akan sesuatu yang bila tidak dipenuhi mendatangkan kesulitan atau mendekati kerusakan. Kondisi semacam ini tidak menghalalkan yang haram. Misalnya, seseorang yang tidak mampu berpuasa maka diperbolehkan berbuka dengan makanan halal, bukan makanan haram.

c. Manfaat, yaitu kepentingan manusia untuk menciptakan kehidupan yang layak. Maka hukum diterapkan menurut apa adanya karena sesungguhnya hukum itu mendatangkan manfaat. Misalnya, makan makanan pokok seperti beras, ikan, sayur-mayur, lauk pauk, dan sebagainya.

d. Fudu, yaitu kepentingan manusia hanya sekedar untuk berlebih-lebihan, yang memungkinkan mendatangkan kemaksiatan atau keharaman. Kondisi semacam ini dikenakan hukum Saddud Dzariah, yakni menutup segala kemungkinan yang mendatangkan kerusakan.

Berdasarkan keempat klasifikasi al-ddharu yuzalu di atas, transaksi lindung nilai pada Pasar Berjangka Komoditi diklasifikasikan pada kemudharatan yang mendatangkan manfaat, karena pada dasarnya manusia memiliki kepentingan untuk menciptakan kehidupan yang layak. Dalam hal ini petani dapat memasarkan hasil panen melalui Pasar Berjangka Komoditi, dimana petani dapat menciptakan harga dan terlindung dari risiko pemasaran.

Fikih lindung nilai syariah di Pasar Berjangka Komoditi juga dapat dihubungkan dengan al-rahnu (gadaian). Hal ini sebagaimana terkandung dalam QS. Al- Baqarah ayat 283. Ayat ini mengisyaratkan bahwa ketika manusia sedang melakukan perjalanan dan terjadi hutang-piutang sampai batas waktu tertentu, dan tidak ditemukan seorang saksi untuk menuliskan perjanjian pada transaksi tersebut, maka hendaknya ada barang jaminan yang dipegang oleh pemberi pinjaman sebagai pengganti saksi tersebut. Dengan demikian, diketahui bahwa petani dalam memasarkan komoditinya pada Pasar Komoditi Berjangka mendapat jaminan dari Lembaga Kliring Berjangka sehingga terhindar dari risiko pemasaran.

Terdapat juga risiko yang harus ditanggung sebagai salah satu tuntutan kontrak tersebut. Dasarnya berdasarkan kaidah fikih yaitu al-ghunm bi al-ghurm (keuntungan yang layak diterima oleh seseorang adalah berdasarkan kadar risiko yang perlu ditanggung). Turunan al-ghunm bi al-ghurm pada kaidah al-Karaj bi al-daman sesuai sabda Nabi saw: "Dari Aisyah bahwa seorang laki-laki membeli seorang budak kemudian budak tersebut tinggal bersamanya selama yang Allah kehendaki. Kemudian si pembeli mendapatkan cacat pada budak tersebut dan melaporkan kepada Nabi saw. Maka Nabi mengembalikan budak itu kepada lakilaki yang menjual. Lalu laki-laki itu berkata, "Wahai Rasulullah, ia (pembeli) telah mempekerjakan (mengambil manfaat) dari budakku". Rasulullah saw. bersabda, "Hak mendapatkan hasil itu disebabkan oleh keharusan menanggung kerugian” (HR. Abu Dawud).

Berdasarkan Hadis ini, al-kharaj merupakan pekerjaan hamba yang telah dibeli seseorang, yang kemudian orang tersebut menyuruh supaya hamba itu bekerja untuknya dalam waktu tertentu. Setelah itu diketahui adanya cacat yang disembunyikan oleh si penjual, kemudian ia dikembalikan kepada penjual tersebut, dengan diambil seluruh uang harganya dan ia telah mendapatkan keuntungan mempekerjakan hamba itu, karena ia telah memberikan pembelanjaannya, dan apabila ada 
kerugian maka ia yang rugi. Dengan demikian, segala sesuatu yang keluar baik berupa pekerjaan, manfaat maupun benda-benda seperti buah dari pohon, susu dari kambing dan sebagainya, yang semuanya adalah menjadi miliki dari yang menanggungnya, sebab kalau ada kerugian maka ia pula yang menanggungnya.

Kaidah al-ghunm bi al-ghurm maknanya adalah profit muncul bersama risiko atau risiko itu menyertai manfaat. Maksud dari kaidah al-ghunm bi al-ghurm ialah bahwa seseorang yang memanfaatkan sesuatu harus menanggung risiko. Sedangkan menurut Umar Abdullah al-Kamil, makna yang tersirat dari kaidah ini adalah bahwa barang siapa yang memperoleh manfaat dari sesuatu yang dimanfaatkannya maka ia harus bertanggung jawab atas dharar atau ghurm serta domain yang akan terjadi (Adinugraha, 2017). Sebagai contoh, penjual perlu menanggung risiko barang yang ingin dijual seperti risiko kerusakan dan kerugian sehingga barang tersebut berpindah milik kepada pembeli. Hanya risiko yang mengandung unsur gharar fahish yang dilarang. Risiko yang tidak termasuk dalam kategori tersebut diperbolehkan menurut syariat Islam sebagai upaya meminimalisirkannya. Instrumen yang digunakan untuk lindung nilai haruslah mematuhi prinsipprinsip yang digariskan oleh syariah. Instrumen tersebut harus terbebas dari unsur penipuan, pertaruhan, dan spekulasi. Selian itu juga penggunaan lindung nilai yang efektif ialah dengan meminimalisir risiko dan tidak menghilangkannya.

Fikih alghumn al-ghurm merupakan salah satu aturan (legalitas) mengenai tingkat imbal hasil atas modal, yang berarti seseorang harus menaggung resiko, jika ada, dan jika ingin mendapatkan keuntungan dari aktivitasnya di Pasar Komoditi Berjangka. Keuntungan harus didapatkan dengan berbagi resiko dan imbal hasil atas kepemilikan melalui penetapan harga komoditi, jasa, atau hak pemakaian atas barang. Kepemilikan barang komoditi tidak dapat dipisahkan dari resiko kerugian yang terkait. Dalam perdagangan di Pasar Komoditi Berjangka, selama barang komoditi tetap berada pada pihak penjual, maka penjual harus menanggung resiko rusaknya barang tersebut, dan ketika ia menjualnya, resiko dialih ke pihak pembeli dengan membayar harga pada waktu yang telah ditetapkan bahkan jika barang komoditi telah rusak karena alasan apapun.

\section{Analisis Ekonomi atas Fatwa DSN NO.96/DSN- MUI/IV/2015 tentang Transaksi Lindung Nilai Syariah di Pasar Berjangka Komoditi}

Perdagangan Berjangka Komoditi di Indonesia telah diatur di dalam peraturan perundang-undangan tersendiri yakni Undangundang Republik Indonesia No. 32 tahun 1997 tentang Perdagangan Berjangka Komoditi, yakni pada pasal 1 ayat (1) disebutkan bahwa Perdagangan Berjangka Komoditi, yang selanjutnya disebut Perdagangan Berjangka, adalah segala sesuatu yang berkaitan dengan jual beli komoditi dengan penyerahan kemudian berdasarkan kontrak berjangka dan opsi atas kontrak berjangka.

Berbeda dengan pengertian kontrak dalam perdagangan biasa, Kontrak Berjangka merupakan kontrak yang standar, dan waktu penyerahan telah ditetapkan terlebih dahulu. Karena bentuknya yang standar, maka yang dinegosiasikan hanya harganya saja. Performance atau terpenuhinya Kontrak Berjangka sesuai dengan spesifikasi yang tercantum dalam kontrak dijamin oleh suatu lembaga khusus, yaitu Lembaga Kliring Berjangka.

UU RI No. 32 tahun 1997 pada ayat (2) pasal yang sama disebutkan bahwa yang dimaksud dengan komoditi adalah barang dagangan yang 
menjadi subjek kontrak berjangka yang diperdagangkan di bursa berjangka. Sedangkan bursa berjangka adalah badan usaha yang menyelenggarakan dan menyediakan sistem dan/atau sarana untuk kegiatan jual beli komoditi berdasarkan kontrak berjangka dan opsi atas kontrak berjangka. Aktivitas jual beli berjangka komoditi, normalnya dilakukan di bursa berjangka komoditi. Karena itu, perdagangan berjangka komoditi ini tidak bisa dipisahkah dari keberadaan bursa berjangka komoditi.

John C. Hull (2003) dalam bukunya Options, Futures Other Derivatives, menjelaskan bahwa Bursa Berjangka Komoditi memiliki peran yang sangat penting dalam aktivitas perdagangan berjangka komoditi. Bursa menentukan kontrak berjangka komoditi dengan standar tertentu. Bursa juga membuat mekanisme yang dapat menjamin ditepatinya kontrak yang dibuat oleh masingmasing pihak.

Pengertian kontrak berjangka disebutkan pada ayat (4) dalam pasal 1 undang-undang yang sama, yaitu suatu bentuk kontrak standar untuk membeli atau menjual komoditi dalam jumlah, mutu, jenis, tempat, dan waktu penyerahan di kemudian hari yang telah ditetapkan, dan termasuk dalam pengertian kontrak berjangka ini adalah opsi atas kontrak berjangka. Selanjutnya diungkapkan bahwa opsi atas kontrak berjangka adalah suatu kontrak yang memberikan hak kepada pembeli untuk membeli atau menjual kontrak berjangka atas komoditi tertentu pada tingkat harga, jumlah, dan jangka waktu tertentu yang telah ditetapkan terlebih dahulu dengan membayar sejumlah premi.

Unsur-unsur yang berpengaruh dalam perdagangan berjangka komoditi, diantaranya adalah hedger, spekulator, dan arbitrator. Hedger adalah pihak yang ingin mengelola risiko atau melakukan hedging (lindung-nilai) dengan mentrasfer semua atau sebagian risiko tersebut kepada yang mau menerimanya. Pihak yang mau menerima transfer risiko tersebut disebut spekulator. Hedger ini mencakup baik penjual maupun pembeli. Apabila hedger yang berposisi sebagai penjual maka disebut short hedger, sedangkan hedger yang berposisi sebagai pembeli long hedger. Para hedger melakukan transaksi berjangka untuk tujuan hedging (lindung nilai). Di sisi lain, spekulator merupakan pihak yang mau mengambil transfer risiko. Spekulan mau mengambil transfer risiko karena berharap akan keuntungan. Dalam tulisannya, Hanafi Sofyan (2000) menyebutkan bahwa spekulan bertransaksi di pasar berjangka untuk mendapatkan keuntungan dari frekuensi harga.

Fluktuasi harga yang terjadi pada bursa berjangka dipengaruhi oleh hukum supply dan demand. Karena bursa berjangka terikat pada law of supply and demand, maka harga di bursa berjangka cenderung bergerak secara paralel. Dengan kemungkinan fluktuasi harga semacam itu, maka baik keuntungan maupun kerugian, sama-sama dapat dialami oleh spekulan perdagangan berjangka. Di samping hedger dan spekulan, dalam perdagangan berjangka ada yang disebut sebagai arbitrator, yaitu orang yang berusaha mendapatkan keuntungan dari selisih harga yang terdapat dalam dua pasar yang berbeda. Aktivitas jual beli berjangka komoditi, normalnya dilakukan di bursa berjangka komoditi. Oleh karena itu, perdagangan berjangka komoditi tidak bisa dipisahkan dari keberadaan bursa berjangka komoditi. Bursa berjangka komoditi memiliki peran yang sangat penting dalam aktivitas perdagangan berjangka komoditi. Bursa menentukan kontrak berjangka komoditi dengan standar tertentu. Bursa juga membuat mekanisme yang dapat menjamin ditepatinya kontrak yang dibuat oleh masingmasing pihak. 
Perdagangan Berjangka Komoditi (PBK) merupakan sarana perdagangan yang dapat dimanfaatkan dunia usaha, termasuk petani dan UMKM, untuk mengamankan kepentingan mereka dari kemungkinan terjadinya kerugian akibat fluktuasi harga. PBK selain berfungsi sebagai sarana pengelolaan resiko, juga berfungsi sebagai sarana terbentuknya harga yang efektif dan transparan sehingga informasi harga yang terbentuk dapat digunakan sebagai referensi berbagai pihak. Dengan demikian, jual beli di bursa komoditi bersifat fluktuatif, naik dan turun terjadi dalam waktu yang cepat. Kondisi ini sering dijadikan keuntungan oleh pihak spekulan yaitu dengan cara membeli pada saat harga rendah dan menjual pada saat harga tinggi, dimana jarak ini dilihat sebagai capital gain yaitu keuntungan yang diperoleh dari selisih harga beli dan harga jual. Kasus yang ditemukan adalah sering sekali para spekulan melakukan aksi ambil untung dengan harga informasi yang tidak lengkap. Kondisi informasi yang tidak lengkap menciptakan pasar yang tidak efisien. Pasar tidak efisien adalah dimana suatu kondisi berbagai informasi tidak dapat diperoleh dengan mudah dan cepat. Adapun pengertian dari pasar efisien adalah suatu kondisi dimana informasi tentang semua harga dapat diperoleh secara terbuka dan cepat tanpa ada hambatan yang khusus.

Peningkatan sektor perdagangan dapat digunakan sebagai sarana meningkatkan kesejahteraan rakyat dan tolok ukur kemajuan suatu negara. Praktik perdagangan di era globalisasi tidak hanya dilakukan dengan cara-cara biasa, seperti ekspor, impor, dan perdagangan dalam negeri, tetapi juga dilakukan dengan metode Perdagangan Berjangka Komoditi. Era globalisasi dan liberalisasi yang berlangsung sangat cepat mendorong terjadinya persaingan bisnis yang semakin ketat di tingkat global yang diiringi dengan terjadinya risiko yang sering merugikan para pelaku usaha. Risiko yang sering terjadi adalah risiko pemasaran (risiko harga), produksi, distribusi, dan pengolahan. Yang paling sulit diprediksi adalah risiko akibat fluktuasi harga komoditi. Harga komoditi di seluruh dunia cenderung berfluktuasi akibat faktor alam (cuaca, musim, bencana alam), kondisi sosial politik, kondisi ekonomi, termasuk maraknya perilaku spekulatif para pelaku pasar komoditi. Indonesia adalah salah satu negara produsen dan eksportir komoditi utama dunia, seperti kopi, kakao, karet, minyak sawit, olein, timah, rumput laut, hasil hutan, dan sebagainya. Sebagai negara produsen, Indonesia perlu mengatasi risiko pemasaran dengan mengembangkan Perdagangan Berjangka.

Rumusan perjanjian baku atau kontrak standar menurut Muhammad Djumhana (2000) harus memenuhi syarat: (a) tidak ada unsur kecurangan, (b) tidak ada unsur pemaksaan akibat ketidakseimbangan kekuatan para pihak, (c) tidak ada syarat perjanjian yang hanya menguntungkan secara sepihak, (d) tidak ada risiko yang hanya dibebankan secara sepihak, serta (e) tidak ada pembatasan hak untuk menggunakan upaya hukum.

Kontrak Berjangka dapat menimbulkan kewajiban kepada pemegang kontrak tersebut untuk melaksanakan pembelian atau penjualan, dimana kedua belah pihak harus melaksanakan kewajiban masing-masing pada tanggal penyerahan atau tanggal penyelesaian akhir (final settlement date). Pada tanggal penyelesaian akhir, pihak penjual akan menyerahkan komoditi yang dijadikan aset acuan kepada pihak pembeli, dan sebaliknya pihak pembeli wajib membeli dengan harga penyelesaian yang telah disepakati dalam kontrak. Harga tertentu yang disepakati pada saat awal kontrak disebut Harga Kontrak Berjangka (futures price). Sedangkan harga dari aset acuan 
pada saat tanggal penyerahan disebut dengan istilah Harga Penyelesaian (settlement price). Apabila Kontrak Berjangka dilakukan dengan cara penyelesaian tunai (tanpa penyerahan barang) maka pelaku perdagangan berjangka yang mengalami kerugian wajib mentransfer sejumlah uang tunai kepada pelaku perdagangan yang memperoleh keuntungan. Kontrak Berjangka dengan penyerahan tunai hanya diperbolehkan kalau harga penyelesaian aset acuan sudah dapat diterima umum. Agar terbebas dari kewajiban pada tanggal penyelesaian akhir, maka pemegang posisi kontrak berjangka harus melakukan perhitungan atas posisinya dengan melakukan penjualan posisi long atau melakukan pembelian kembali posisi short yang secara efektif akan menutup posisi kontrak berjangka serta menutup kewajibannya berdasarkan kontrak tersebut.

Pelaku perdagangan berjangka pada umumnya dimasukkan dalam dua kelompok yaitu: (a) pelaku lindung nilai (hedger) yang memiliki kepentingan pada aset acuan dan mencari cara untuk melindungi aset dari risiko perubahan harga, serta (b) pencari untung (spekulator) yang berorientasi memperoleh keuntungan dengan cara melakukan prediksi atas pergerakan harga pasar dan melakukan pembelian komoditi di atas kertas meskipun mereka tidak membutuhkan komoditi tersebut.

Bursa berjangka memiliki dua fungsi ekonomi yang sangat penting; yakni transfer risiko dan penemuan harga. Dengan adanya bursa berjangka, kemungkinan kerugian yang mungkin dialami pelaku bisnis akibat fluktuasi harga dapat dikurangi ataupun ditanggulangi sama sekali. Di pasar berjangka juga terjadi penemuan harga dan di bursa berjangka, spekulan dan hedger bertemu, dengan demikian mereka akan menyepakati harga atas suatu komoditi (Sofyan, 2000). Dengan kata lain, manfaat utama dari perdagangan berjangka komoditi adalah sebagai sarana pengelolaan risiko (risk management) melalui kegiatan lindung-nilia dan sarana pembentukan harga (price discovery).

Manfaat pada faktor-faktor yang sulit dikuasai seperti kelainan musim, bencana alam, dan lain-lain. Dengan kegiatan lindung-nilai menggunakan kontrak berjangka, mereka dapat mengurangi sekecil mungkin dampak (risiko) yang diakibatkan gejolak harga tersebut. Dengan memanfaatkan Kontrak Berjangka, produsen komoditi dapat menjual komoditi yang baru akan mereka panen beberapa bulan kemudian pada harga yang telah dipastikan atau disepakati sebelum panen dilakukan. Dengan demikian, mereka dapat memperoleh jaminan harga sehingga tidak terpengaruh oleh kenaikan/penurunan harga jual di pasar tunai. Sedangkan eksportir dapat melakukan pembelian komoditi di masa yang akan datang, pada saat harus memenuhi kontraknya dengan pembeli di luar negeri, atau pengolah yang harus melakukan pembelian komoditi secara berkesinambungan.

Manfaat ekonomi lainnya adalah sebagai sarana pembentukan harga yang transparan dan wajar, yang mencerminkan kondisi pasokan dan permintaan yang sebenarnya dari komoditi yang diperdagangkan. Hal ini dimungkinkan karena transaksi hanya dilakukan oleh/melalui anggota bursa, mewakili nasabah atau dirinya sendiri, yang berarti antara pembeli dan penjual Kontrak Berjangka tidak saling kenal/mengetahui secara langsung. Harga yang terjadi di bursa umumnya dijadikan sebagai harga acuan (reference price) oleh dunia usaha, termasuk petani dan produsen/pengusaha kecil, untuk melakukan transaksi di pasar fisik.

Komoditi yang menjadi subjek Kontrak Berjangka yang diperdagangkan di Bursa adalah komoditi pertanian, kehutanan, pertambangan, 
industri hulu, serta jasa. Setiap komoditi yang kontraknya diperdagangkan di Bursa, spesifikasinya ditetapkan secara jelas, menyangkut jumlah, kualitas, dan waktu penyerahan sehingga para pemakai/pengguna Bursa dengan mudah dapat melakukan transaksinya. Dengan demikian, pasar yang aktif dan likuid akan terwujud. Di samping hedger, yang dapat menggunakan Kontrak Berjangka untuk mengurangi risiko adalah investor/ spekulan. Spekulan dapat mencari keuntungan dari adanya fluktuasi harga. Spekulan biasanya membeli Kontrak Berjangka pada saat harga rendah dan menjualnya pada saat harga naik, atau sebaliknya menjual Kontrak Berjangka pada saat harga diperkirakan akan mengalami penurunan dan membelinya kembali pada saat harga rendah.

Berdasarkan pendapat di atas, Perdagangan Berjangka Komoditi mempunyai manfaat ekonomi karena cara ini dapat digunakan sebagai sarana lindung nilai (hedging) dan sarana penciptaan harga (price discovery). Perdagangan Berjangka juga dapat menghasilkan harga rujukan (reference of price) yang transparan untuk digunakan sebagai harga acuan di tingkat dunia. Dengan menggunakan cara Perdagangan Berjangka, para pelaku usaha khususnya petani kecil juga dapat terlindungi dari risiko pemasaran. Hal ini juga ditegaskan dalam Fatwa DSN No.96/DSNMUI/IV/2015 tentang Transaksi Lindung Nilai Syariah di Pasar Berjangka Komoditi, bahwa lindung nilai atas nilai tukar merupakan cara atau teknik untuk mengurangi risiko yang timbul maupun yang diperkirakan akan timbul akibat adanya fluktuasi nilai tukar. Sedangakan transaksi lindung nilai merupakan transaksi dengan skema berupa rangkaian transaksi jual-beli komoditi (sil'ah) dalam mata uang rupiah yang diikuti dengan jual-beli komoditi (sil'ah) dalam mata uang asing serta penyelesaiannya berupa serah terima mata uang pada saat jatuh tempo.

\section{Kesimpulan}

Penelitian ini menyimpulkan bahwa pertama, analisis Fikih atas Fatwa Dewan Syariah Nasional No. 96/DSN-MUI/IV/2015 Tentang Transaksi Lindung Nilai Syariah di Pasar Berjangka Komoditi, ditemukan adanya pandangan yang berbeda terhadap dalil-dalil yang ditemukan. Ulama yang melarang perdagangan berjangka komoditi, mengkaji dari syarat-syarat akad yaitu akad baru dapat terpenuhi jika waktu akad dibuat, barang obyek akad harus ada pada penjual atau jelas keberadaan barangnya. Juga bahwa obyek jual beli harus merupakan barang yang dimiliki oleh penjual atau mendapatkan izin dari pemiliknya, jika barang itu bukan milik si penjual. Larangan tersebut menyangkut jual beli benda tertentu dan tidak meliputi barang dalam tanggungan, adanya kesamaan dalam perdagangan berjangka ini dengan spekulasi (gharar), serta penetapan margin yang persentasenya berkisar antara 5-10\% dalam Islam dapat masuk ke dalam kategori riba, karena telah ditentukan berapa pembagian yang semestinya harus diterima oleh salah satu pihak tertentu dari pihak-pihak yang bertransaksi itu. Sedangkan yang memperbolehkan berpendapat dengan alasan meskipun barang belum ada tapi dapat diadakan dan diserahkan kemudian, diperbolehkan memperjualbelikannya, dan memandang perdagangan berjangka tidak dapat dikategorikan dengan spekulasi. Kedua, analisis ekonomi Islam atas Fatwa Dewan Syariah Nasional No. 96/DSNMUI/IV/2015 Tentang Transaksi Lindung Nilai Syariah di Pasar Berjangka Komoditi, diantaranya produsen komoditi dapat menjual komoditi yang baru akan mereka panen beberapa bulan kemudian pada harga yang telah dipastikan atau disepakati sebelum panen dilakukan. Dengan demikian, mereka dapat memperoleh jaminan harga sehingga tidak terpengaruh oleh kenaikan/penurunan harga jual di pasar tunai. Sedangkan eksportir dapat 
melakukan pembelian komoditi di masa yang akan datang, pada saat harus memenuhi kontraknya dengan pembeli di luar negeri, atau pengolah yang harus melakukan pembelian komoditi secara berkesinambungan. Selain itu juga, Pasar Berjangka Komoditi dapat dijadikan sebagai sarana pembentukan harga yang transparan dan wajar, yang mencerminkan kondisi pasokan dan permintaan yang sebenarnya dari komoditi yang diperdagangkan. Hal ini dimungkinkan karena transaksi hanya dilakukan oleh/melalui anggota Bursa, mewakili nasabah atau dirinya sendiri, yang berarti antara pembeli dan penjual Kontrak Berjangka tidak saling kenal/mengetahui secara langsung. Harga yang terjadi di bursa umumnya dijadikan sebagai harga acuan (reference price) oleh dunia usaha, termasuk petani dan produsen/pengusaha kecil, untuk melakukan transaksi di pasar fisik.

\section{Daftar Pustaka}

Adinugraha, H. H. (2017). Penerapan Kaidah alGhunm bi al-Ghurm dalam Pembiayaan Mushārakah pada Perbankan Syariah. Economica: Jurnal Ekonomi Islam, 8(1), 81102.

Anwar, S. (2007). Hukum Perjanjian Syari'ah: Studi Tentang Teori Akad dalam Fikih Muamalat. Raja Grafindo Persada.

Az-Zuhaili, W. (2011). Fikih Islam Wa-Adillatuh (A. H. Al-Kattani (ed.)). Gema Insani.

Djumhana, M. (2000). Hukum Perbankan di Indonesia. Citra Aditya Bakti.

Hull, J. C. (2003). Options futures and other derivatives. Pearson Education India.

Kuenaen, \& Ridwan. (2001). Aspek Perlindungan Bagi Pelaku Bisnis didalam Perdagangan Berjangka. Seminar Nasional Peran Perdagangan Berjangka Sebagai Sarana Pembentukan Harga Dan Lindung Nilai.

Nordin, N., Rahman, A. A., \& Omar, H. H. (2014). The Islamic hedging management: Paving the way for innovation in currency options. International Journal of Management Studies, 21(1), 23-37.
Rahman, A. (1996). Doktrin Ekonomi Islam. Dana Bhakti Wakaf.

Shihab, M. Q. (2000). Tafsir Al-Mishbah Pesan, Kesan, dan Keserasian Al-Quran. Lenteng Hati.

Sofyan, H. (2000). Perdagangan Berjangka dan Ekonomi Indonesia. Elex Media Komputindo.

Sutedi, A. (2012). Produk-produk Derivatif dan Aspek Hukumnya. Alfabeta.

Yakubu, M. N., \& Dasuki, S. I. (2019). Factors affecting the adoption of e-learning technologies among higher education students in Nigeria. Information Development, 35(3), 492-502.

https://doi.org/10.1177/0266666918765907 